\title{
Low viscosity oils impact on Heavy Duty Diesel engine components
}

\author{
Edney Deschauer Rejowski, Dr. Eduardo Tomanik, Juliano Pallaoro Souza \\ MAHLE Metal Leve SA \\ E-mails: edney.rejowski@br.mahle.com, eduardo.tomanik@br.mahle.com, \\ juliano.souza@br.mahle.com
}

\begin{abstract}
Increasing fuel costs and stringent emissions standards in the world became the most important challenges for the transportation industry. The use of low viscosity oils is considered an effective way to reduce fuel consumption of Heavy Duty Diesel (HDD) engines. However, the impact of oil viscosity reduction and novel additive packages needs to be better understood in durability of engine components. This paper investigated the application of a low viscosity oil SAE 10W-30 (HTHS 2.9cP) with novel formulation prepared to withstand EURO VI and OEM demands, through a 500 hours durability dynamometer test with extended oil drainage interval. The main tribo system such as liner-rings-piston, rod bushing-pin-piston and rod-bearing-crankcase were evaluated in terms of wear impact by visual and dimensional analyzes. The results obtained with low viscosity oil test were compared with the same engine components which were tested with typical SAE15W-40 oil (HTHS 3.7cP min.) applied in EURO V/VI HDD engines. From the comparative analyses, it was possible to identify some engine components that do not require design updates or technologies changes. For others, it was possible to anticipate performance issues that will demand new design and or material upgrades. Oil analyses were done each $50 \mathrm{~h}$ of test. The oil degradation due to the extended drainage time is discussed in this paper.
\end{abstract}

\section{INTRODUCTION}

Reducing viscosity of engine oil is considered one of the most interesting options for reducing friction losses; hence fuel consumption [1]. However, low viscosity oils may lead to higher wear rate, that if not solved can lead to increased maintenance costs and a reduced engine life, consequently increase on overall fleet operating costs. To counter the expected wear increase, work is being done to improve the lube additives $[2 ; 3]$. Studies about wear with different viscosities and additive chemistry on combustion engines using bench tests, virtual simulations and short running test in dyno were reported $[4-8,10]$.

Lower viscosity oils will increase their market share. A survey with heavy duty diesel engine fleet managers, suggested that the market share of $10 \mathrm{~W}-30$ oils will grow from about $6 \%$ to roughly $20 \%$ by 2022 [6].

The engine components experiment different lubrication regimes depending on the speed, pressure and temperature conditions. Such regimes are usually summarized in the "Stribeck" curve (see figure 1), where $\mu$ is the lubricant viscosity, $v$ is the relative speed of the surfaces and $p$ is the normalized load. Lower viscosity oils reduce the hydrodynamic friction but tend to lead to higher boundary contact. Anti-wear additives 
are thought to be active in the boundary and mixed lubrication regimes. In general this class of additives, with zinc-dithiophosphates (ZnDTP) as the most commonly used in combustion engine oils, deposits a solid anti-wear film onto the surface. In addition to anti-wear additives, detergents are also known to impact wear phenomena as additives from this class of components are surface active and form solid films on a metal surface $[4,8]$.

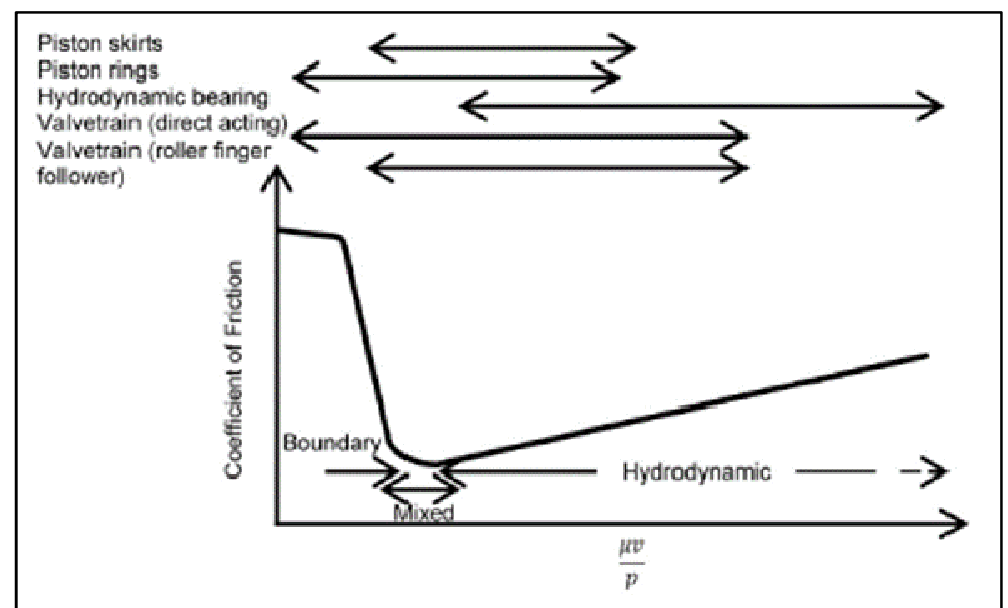

Figure 1 - Stylized "Stribeck Curve" [9]

Figure 2 summarizes wear on cylinder liner surface at Top Dead Center (TDC) region after short HDD engine tests $(80 \mathrm{~h})$ with different candidates of anti-wear additives applied in two base oil variants: $15 \mathrm{~W}-40$ (HTHS $4.35 \mathrm{cP}$ ) and 0W-40 (HTHS $3.81 \mathrm{cP}$ ). While five out of the six evaluated $15 \mathrm{~W}-40$ formulations showed up to $20 \%$ reduction in liner wear, the difference that stands out the most is the increase in liner wear for the $0 \mathrm{~W}-40$ oils relative to the $15 \mathrm{~W}-40$ oils. It is also clear the impact of different additive packages even with same oil viscosity [4].

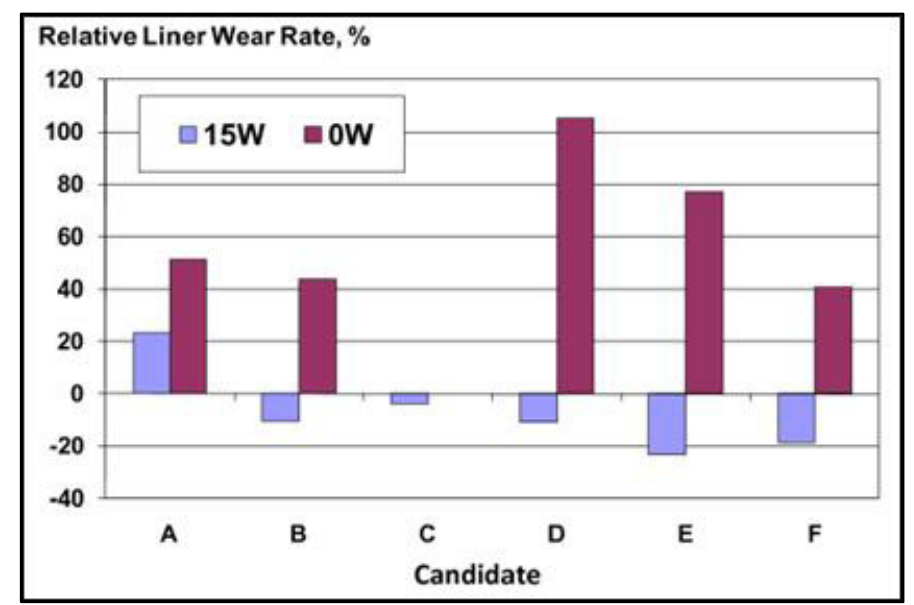

Figure 2 - Viscosity grade and anti-wear package impact on liner wear [4].

\section{LOW VISCOSITY LUBE OILS FOR MODERN HDD ENGINES}

Table 1 summarizes the SAE viscosity grades. In this work, a SAE15W-40 (HTHS $3.7 \mathrm{cP}$ ) currently used in Brazil and a 10W-30 (HTHS 2.9cP) candidate for the European 
next generation engine were tested in the same engine, as described ahead. Additive package followed the lube generation, so not only the viscosity was changed from one oil to another.

Table 1 - SAE J300 engine oil viscosity grades (as Jan 2015) [8]

\begin{tabular}{|c|c|c|c|c|c|}
\hline \multirow[t]{2}{*}{$\begin{array}{c}\text { SAE } \\
\text { Grade } \\
\text { Viscosity }\end{array}$} & \multirow[t]{2}{*}{$\begin{array}{l}\text { Low Temp. } \\
\left({ }^{\circ} \mathrm{C}\right) \text { Cranking } \\
\text { Viscosity, } \\
\text { mPa.s, max. }\end{array}$} & \multirow[t]{2}{*}{$\begin{array}{l}\text { Low Temp. }\left({ }^{\circ} \mathrm{C}\right) \\
\text { Pumping } \\
\text { Viscosity, mPa.s, } \\
\text { Max, w/ no Yield } \\
\text { Stress }\end{array}$} & \multicolumn{2}{|c|}{$\begin{array}{c}\text { Low Shear Rate } \\
\text { Kinematic } \\
\text { Viscosity }\left(\mathrm{mm}^{2} / \mathrm{s}\right) \\
\text { at } 100^{\circ} \mathrm{C}\end{array}$} & \multirow{2}{*}{$\begin{array}{l}\text { High Temp. } \\
\text { High Shear } \\
\text { mPa.s at } 150^{\circ} \mathrm{C}, \\
\text { min. }\end{array}$} \\
\hline & & & Min & Max & \\
\hline $0 \mathrm{~W}$ & 6,200 at $-35^{\circ} \mathrm{C}$ & 60,000 at $-40^{\circ} \mathrm{C}$ & 3.8 & - & - \\
\hline $5 \mathrm{~W}$ & 6,600 at $-30^{\circ} \mathrm{C}$ & 60,000 at $-35^{\circ} \mathrm{C}$ & 3.8 & - & - \\
\hline $10 \mathrm{~W}$ & 7,000 at $-25^{\circ} \mathrm{C}$ & 60,000 at $-30^{\circ} \mathrm{C}$ & 4.1 & - & - \\
\hline $15 \mathrm{~W}$ & 7,000 at $-20^{\circ} \mathrm{C}$ & 60,000 at $-25^{\circ} \mathrm{C}$ & 5.6 & - & - \\
\hline $20 \mathrm{~W}$ & 9,500 at $-15^{\circ} \mathrm{C}$ & 60,000 at $-20^{\circ} \mathrm{C}$ & 5.6 & - & - \\
\hline $25 \mathrm{~W}$ & 13,000 at $-35^{\circ} \mathrm{C}$ & 60,000 at $-15^{\circ} \mathrm{C}$ & 9.3 & - & - \\
\hline 8 & - & - & 4.0 & $<6.1$ & 1.7 \\
\hline 12 & - & - & 5.0 & $<7.1$ & 2.0 \\
\hline 16 & - & - & 6.1 & $<8.2$ & 2.3 \\
\hline 20 & - & - & 6.9 & $<9.3$ & 2.6 \\
\hline 30 & - & - & 9.3 & $<12.5$ & 2.9 \\
\hline 40 & - & - & 12.5 & $<16.3$ & $3.5^{(\mathrm{a})}$ \\
\hline 40 & - & - & 12.5 & $<16.3$ & $3.7^{(b)}$ \\
\hline 50 & - & - & 16.3 & $<21.9$ & 3.7 \\
\hline 60 & - & - & 21.9 & $<26.1$ & 3.7 \\
\hline
\end{tabular}

\section{ENGINE TEST}

A 13.0 liter, 6 cyl. HDD engine with 220 bar of Peak Combustion Pressure (PCP) was tested during $500 \mathrm{~h}$ with each lube formulation. Oil drainage time followed the OEM recommended interval: $150 \mathrm{~h}$ for the current oil $^{1}(15 \mathrm{~W}-40)$ and $500 \mathrm{~h}$ for the next generation low viscosity (10W-30) one. The engine test with current oil used current production engine components (typical technologies in series production for HDD EUR 5 engines) and the test with low viscosity had some cylinders with production parts and others with higher wear resistant products to allow both the comparison between oils and between component alternatives with the low viscosity oil.

Test procedure was $20 \mathrm{~h}$ break-in followed by $500 \mathrm{~h}$ in a durability cycle. Engine performance curve was done before and after the 500h durability test. Figure 3 shows the values at test start, no performance degradation was observed at test end. Fuel was the Brazilian Diesel S10 B5to7. Lube Oil consumption was measured by drain and weight every $50 \mathrm{~h}$, when also a small lube sample was removed for analysis. In case of SAE 10W-30 oil, small amount of fresh oil was added every 50h just to reach the engine oil volume requirement for dyno test.

\footnotetext{
${ }^{1}$ Due to leakage issues, the SAE $15 \mathrm{~W}-40$ had the oil exchanged at 150,300 and $350 \mathrm{~h}$.
} 


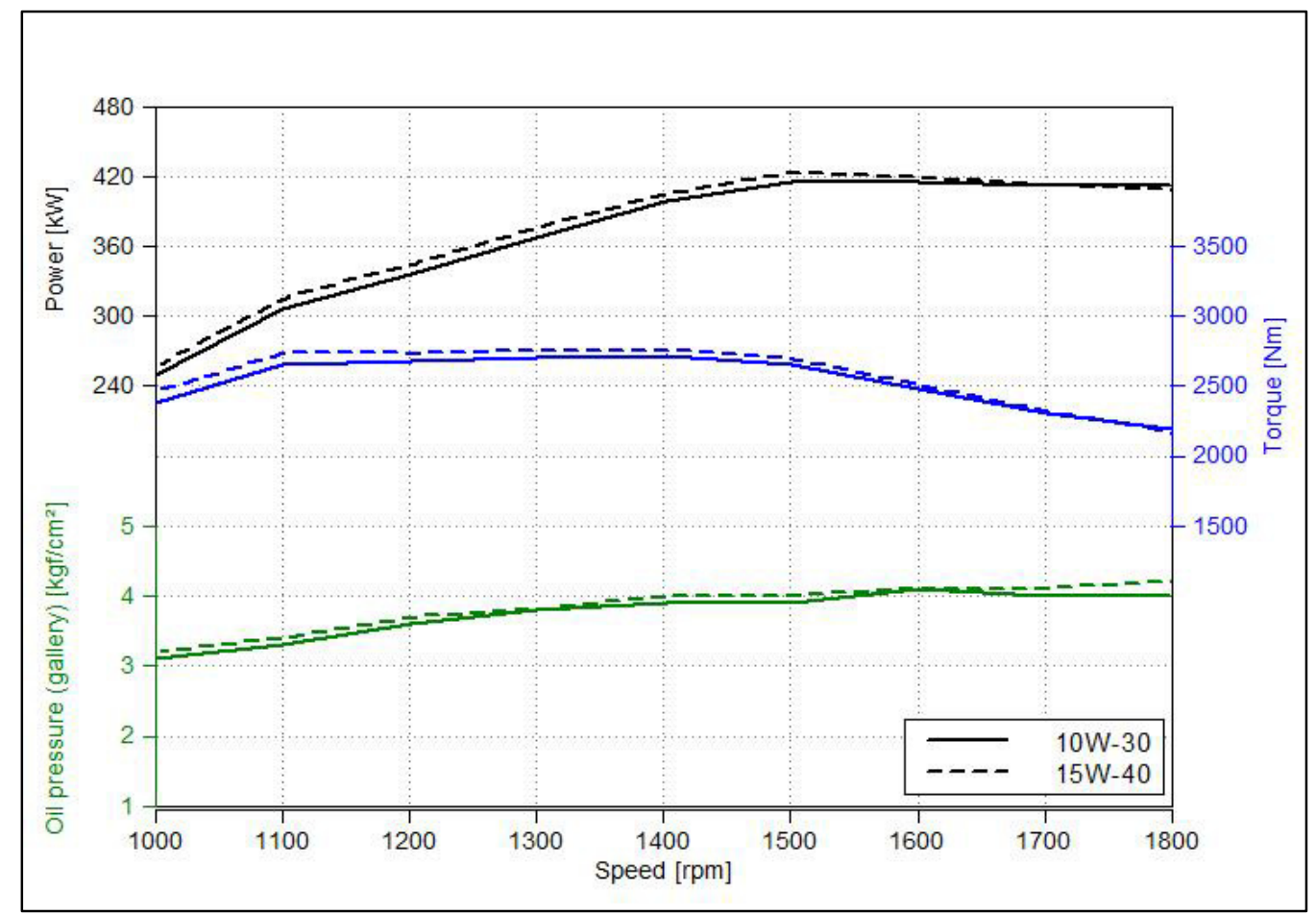

Figure 3- Performance curves at test start.

Eventual fuel saving with the lower viscosity oil would demand a more precise dynamometer than the used in this work and was not the scope of this investigation. Blow-by and Lube Oil Consumption (LOC) as well other engine parameters along the test were according the manufacturer limits. See table 2.

Table 2 - Blow and LOC data along the test

\begin{tabular}{|l|c|c|}
\hline & SAE $15 \mathrm{~W}-40$ oil & SAE $10 \mathrm{~W}-30$ oil \\
\hline Blow-by $[1 / \mathrm{min}]$ & $155-165$ & $130-140$ \\
\hline LOC $[\mathrm{g} / \mathrm{h}]$ & $18-31$ & $12-21$ \\
\hline
\end{tabular}

\subsection{LUBRICANT OIL ANALYSES}

Lube oil was analyzed every $50 \mathrm{~h}$ during engine test. Base number (BN - ASTM D2896), acid number (AN - ASTM D664), oil viscosity @ $100^{\circ} \mathrm{C}$ (ASTM D 445), metal presence and some additive components such as Mo, Zn and P (ASTM D4951) were monitored by ICP-OES (Inductively Coupled Plasma - Optical Emission Spectrometer).

BN and AN were in regular condition after 500 hours of test in both oil variants, see Figure 4. After 500h, with not oil change, the 10W-30 oil had almost BN and AN "crossed", i.e. reaching the same value, which is usually considered as limit to oil change. Nevertheless, BN decay of the $10 \mathrm{~W}-30$ was lower than with the $15 \mathrm{~W}-40$, the latter, without oil change, would have BN-AN crossing around $300 \mathrm{~h}$. Viscosity of both oils was within their respective SAE specification ("they stay in grade along the test") during $500 \mathrm{~h}$ engine tests. See figure 5. 


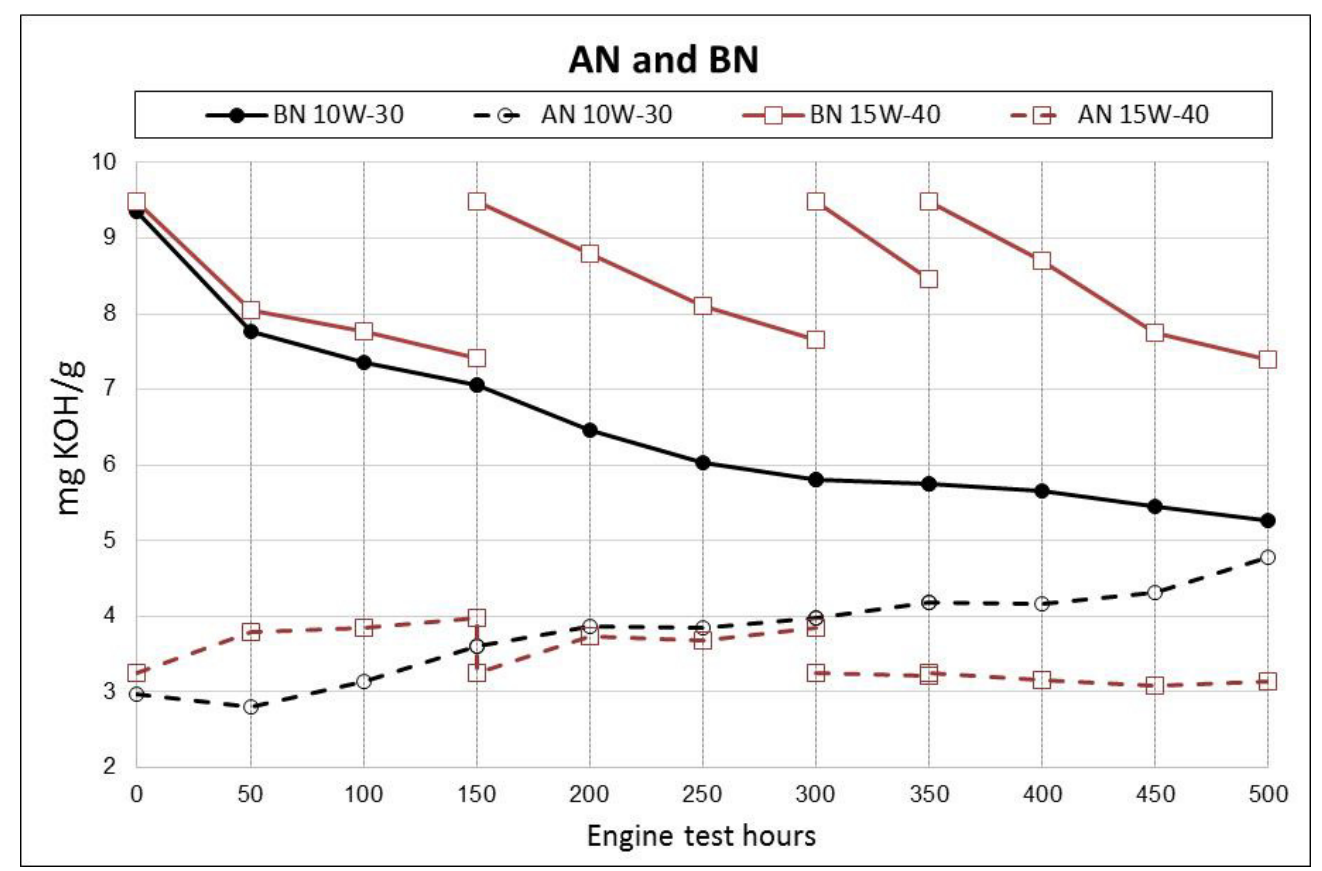

Figure $4-\mathrm{AN}$ and $\mathrm{BN}$ oil analyses during 500h engine tests.

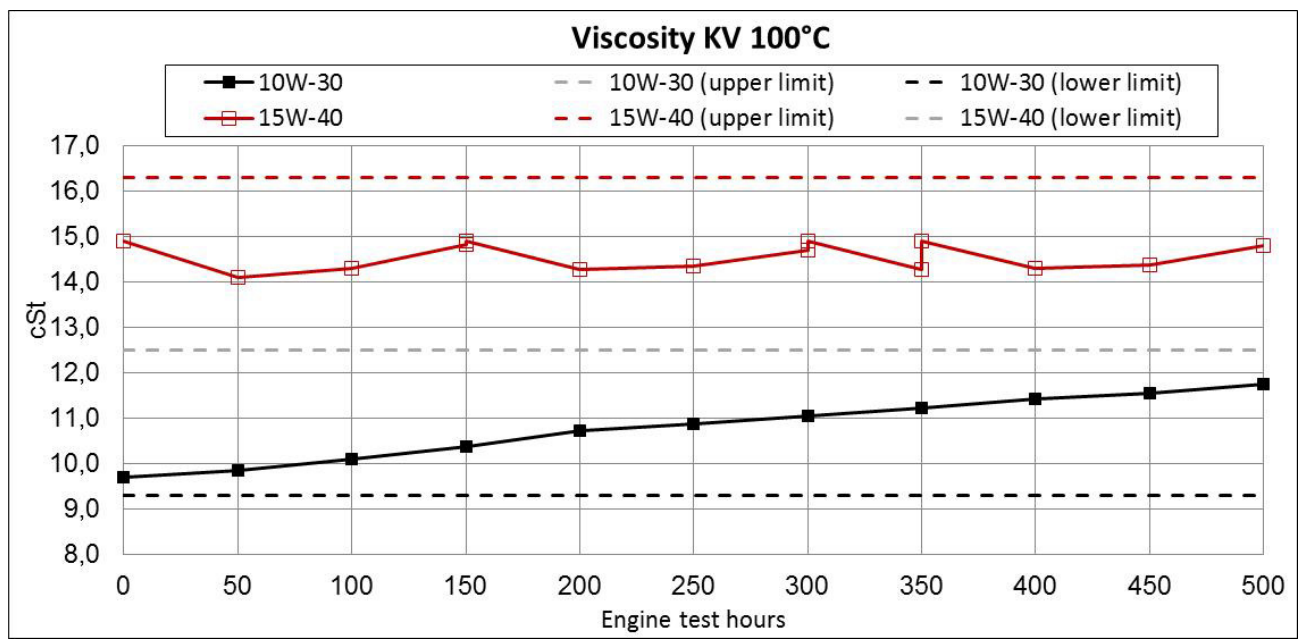

Figure 5 - Lube oil viscosity at $100^{\circ} \mathrm{C}$ during $500 \mathrm{~h}$ engine tests.

Metal presence analysis showed a constant and significant increase of Fe content (up to $171 \mathrm{ppm})$ and peak of $\mathrm{Cu}$ content (200 ppm) at 200h engine test in the low viscosity oil test. Sources for both metals were not identified on the analyzed engine parts, see ahead. For better comparison, figure 6 shows the accumulated metal values for the SAE $15 \mathrm{~W}$ 40 , i.e. the values represent what would accumulate if oil was not changed along the test. Metal accumulated values were higher in the test with the low viscosity oil and longer drainage interval. 


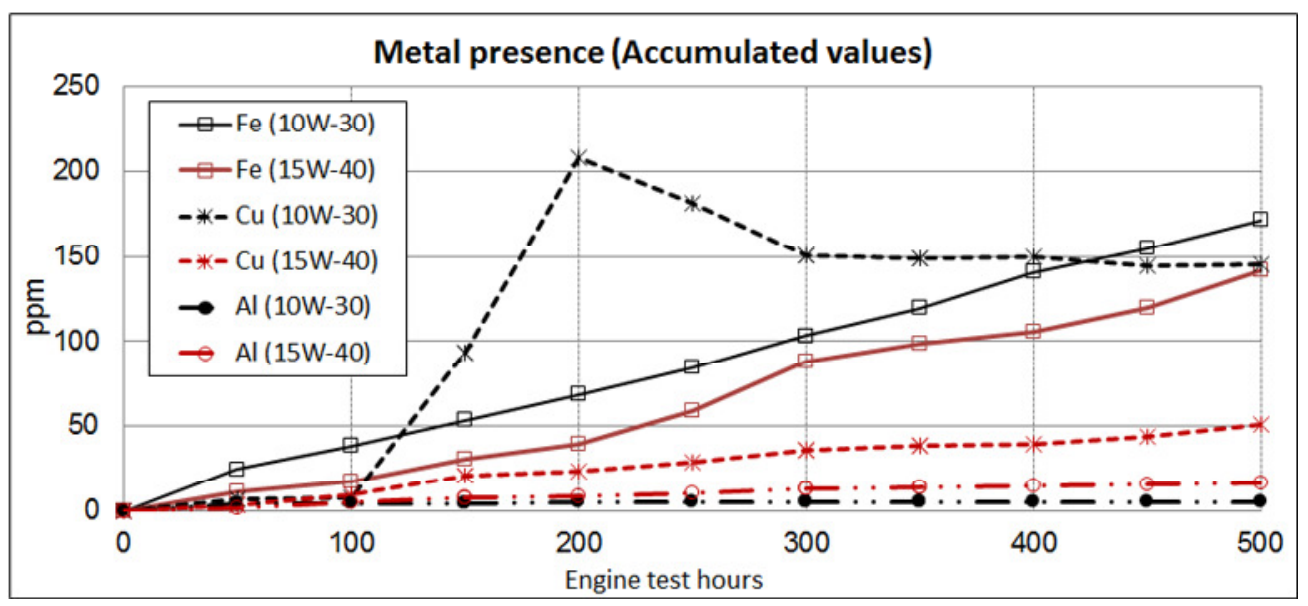

Figure 6 - Metal presence during 500h engine tests.

$\mathrm{Zn}$ and $\mathrm{P}$ analysis showed slight higher contents in the $15 \mathrm{~W}-40$. The $10 \mathrm{~W}-30$ oil goes in the trend of reducing SAPs. Zn and P variation along test was small for both oils. See Figure 7. Analyses indicate around $60 \mathrm{ppm}$ of Mo in the $10 \mathrm{~W}-30$ and no Mo presence in the $15 \mathrm{~W}-40$ oil.

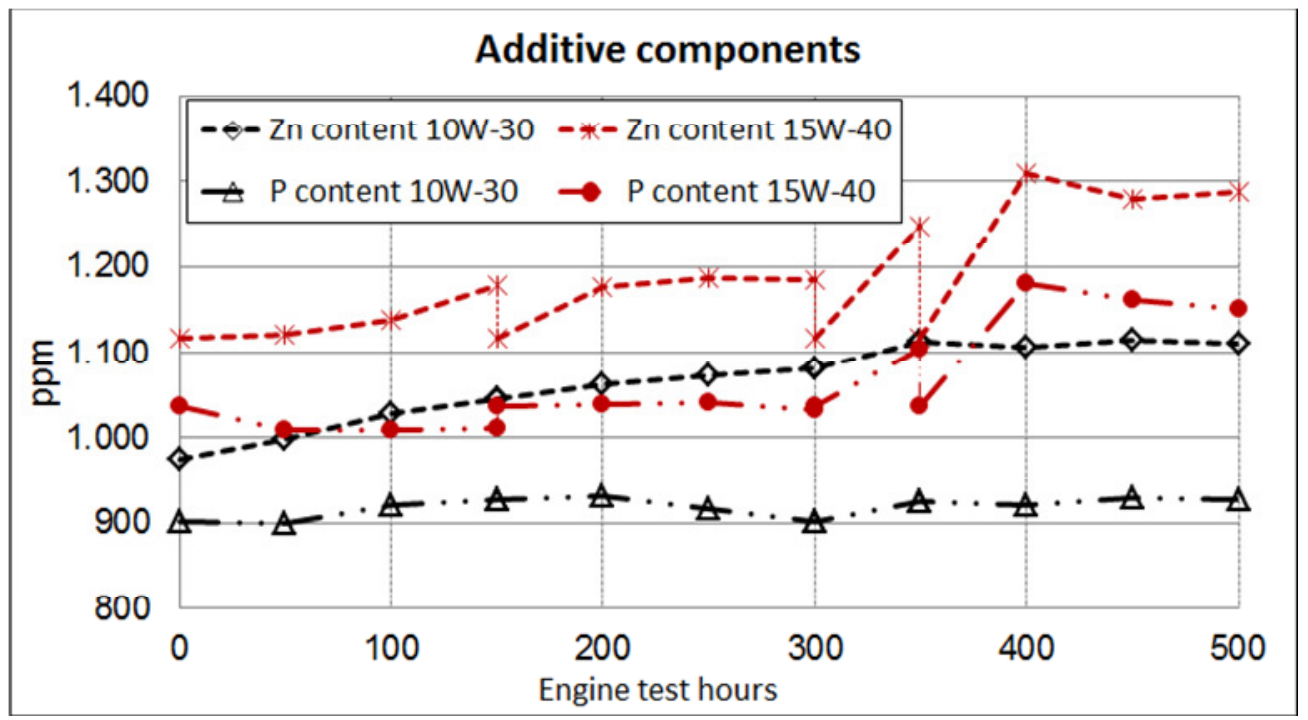

Figure $7-\mathrm{Zn}$ and $\mathrm{P}$ content along the tests.

\subsection{PISTON}

MAHLE Monotherm steel (38MnBVS6) pistons with graphite coating on the skirt surface were assembled in both engine tests. After 500h test, carbon deposits at top lands were small and similar with both oils and all rings were free to rotate, see figure 8. Piston groove, skirt and pin wear was too low in both tests to be measured by conventional methods. 


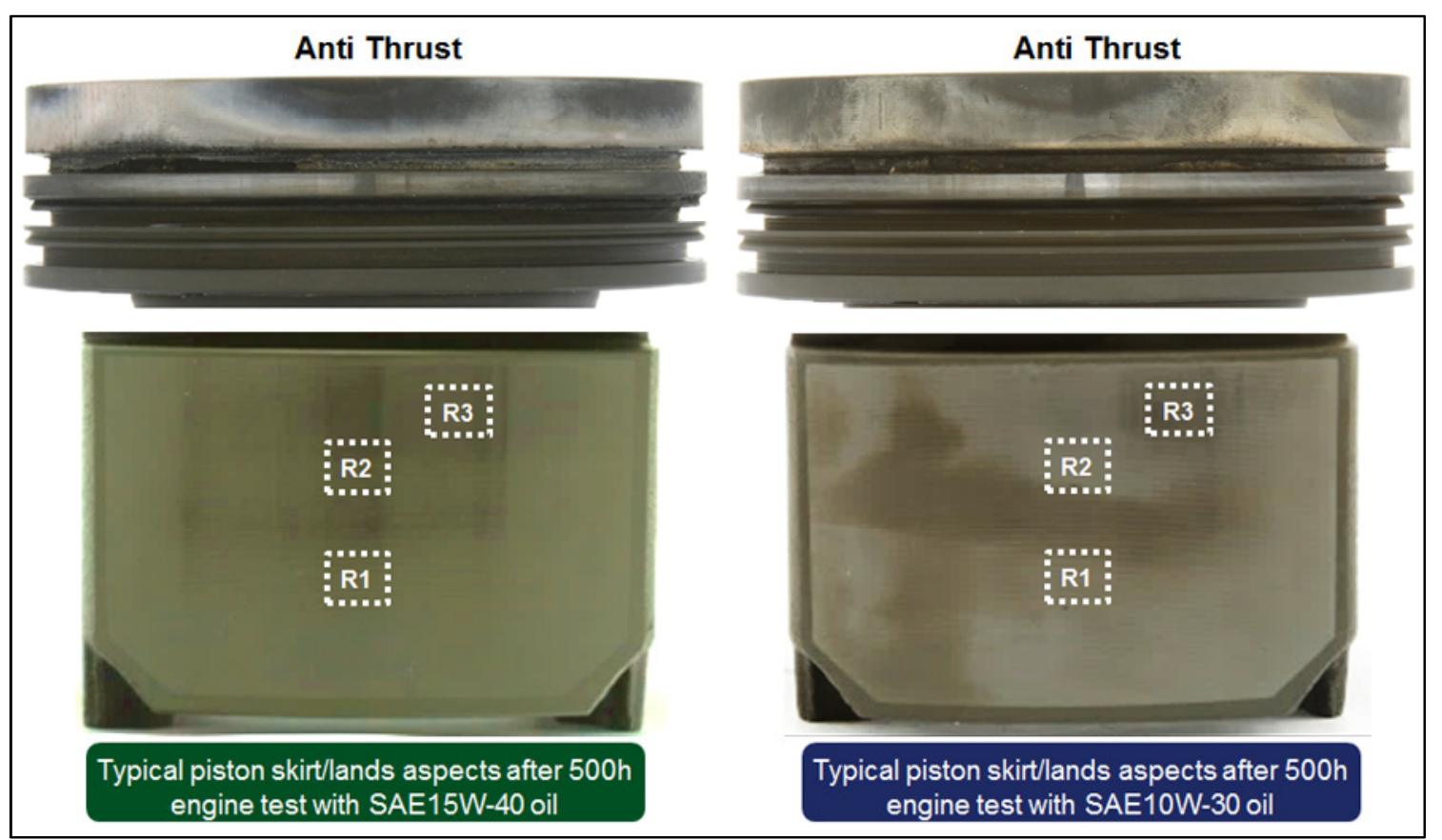

Figure 8 - Visual aspects of piston ATS after tests.

\subsection{PISTON PINS}

Current piston pin, made in $16 \mathrm{MnCr} 5$ steel, was assembled in both engine tests. Outside diameter and roughness were measured before and after engine tests. No signs for concerned were found. See Figure 9 and 10.

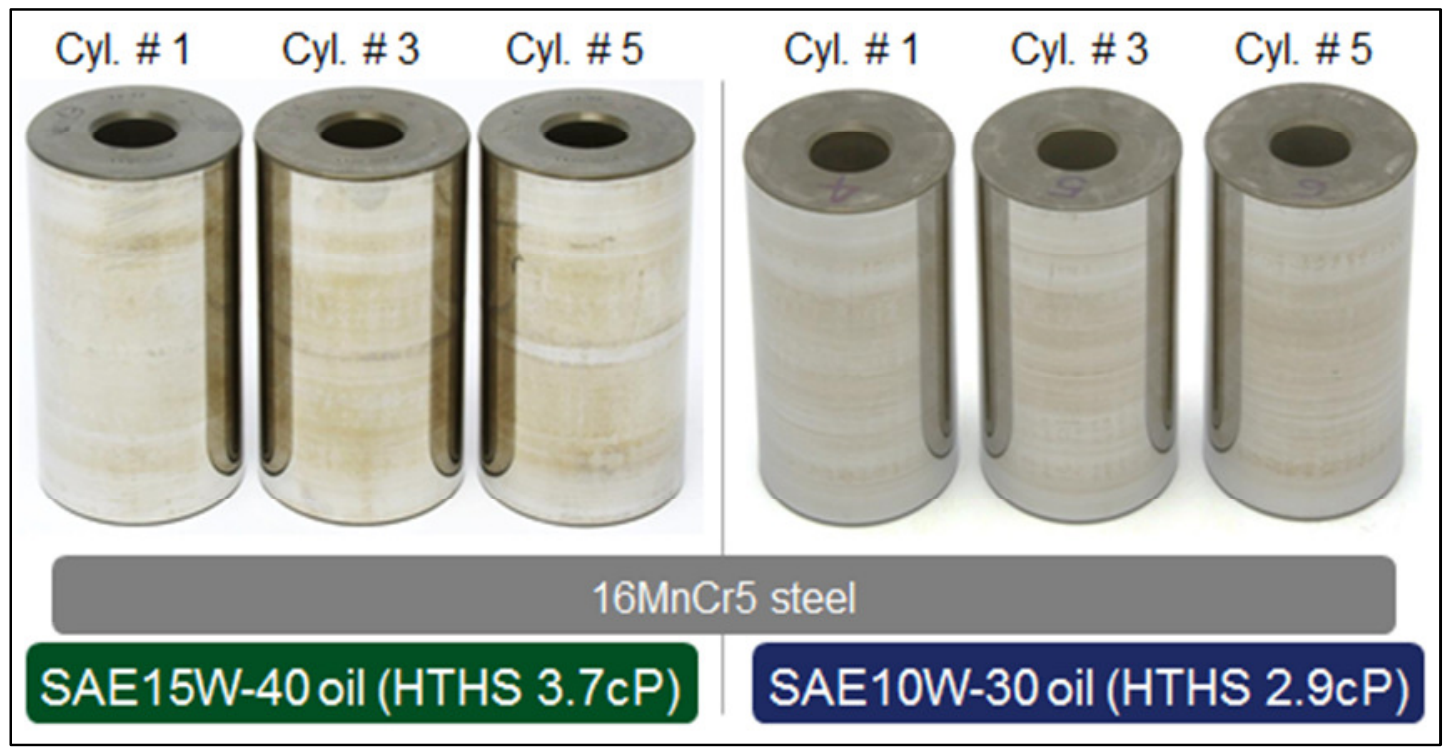

Figure 9 - Piston pins after 500h engine tests. 


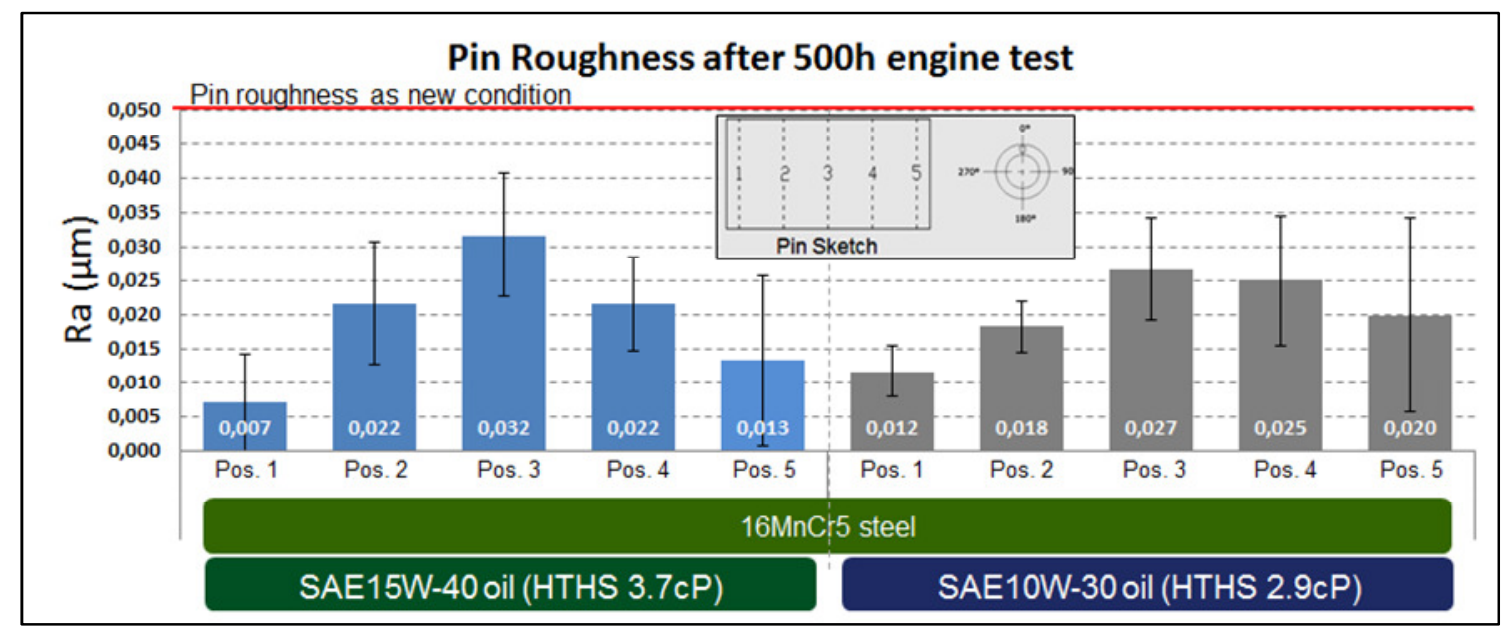

Figure 10 - Piston pin roughness measurements after 500h engine tests

\subsection{PISTON RINGS}

The current top ring with CrN PVD coating [11] in the running face over Gas nitrited steel (GNS) were tested with both oil variants. In the 10W-30 test, 3 cylinders (cyls) were assembled a high wear resistance DLC H-free coating over CrN PVD surface [13]. After test, both top ring variants presented good visual aspect without burning marks, cracks or coating spallation. In the 10W-30 test, the CrN PVD top ring presented $18 \%$ avg. wear increase in the contact face, while the DLC H-Free showed wear reduction of 44\% compared to CrN. See figures 11 and 12. The DLC H-free with the low viscosity oil showed lower wear than the current ring with the $15 \mathrm{~W}-40$.

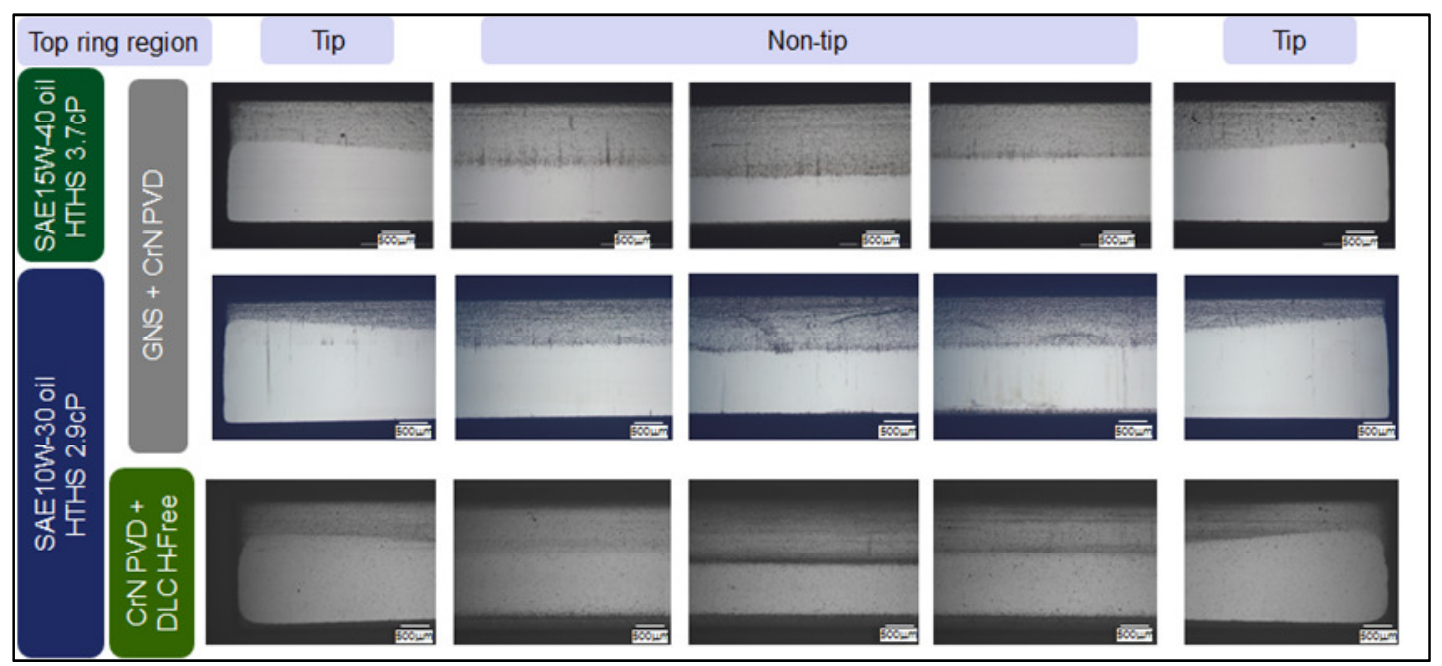

Figure 11 - Visual aspects of top ring sets after 500h HDD engine tests. 


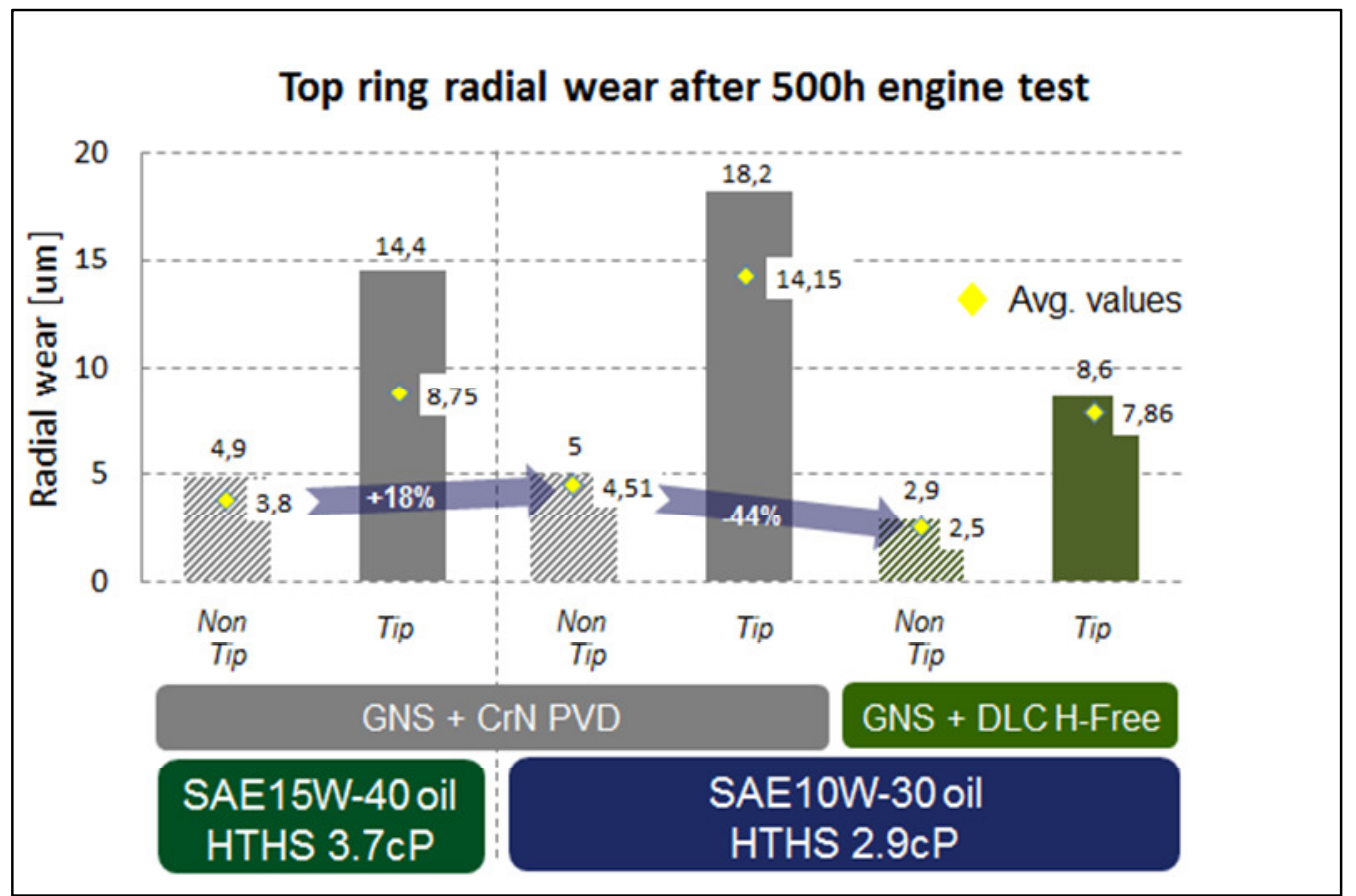

Figure 12 - Radial wear of top ring after 500h engine tests.

Similar evaluation was done for $2^{\text {nd }}$ rings, where a more wear resistance CrN PVD coating over GNS ring was compared to the current GNS. Again, no issues were found, and the more resistant variant presented lower wear with the low viscosity oil than the current ring with the current oil. See figure 13.

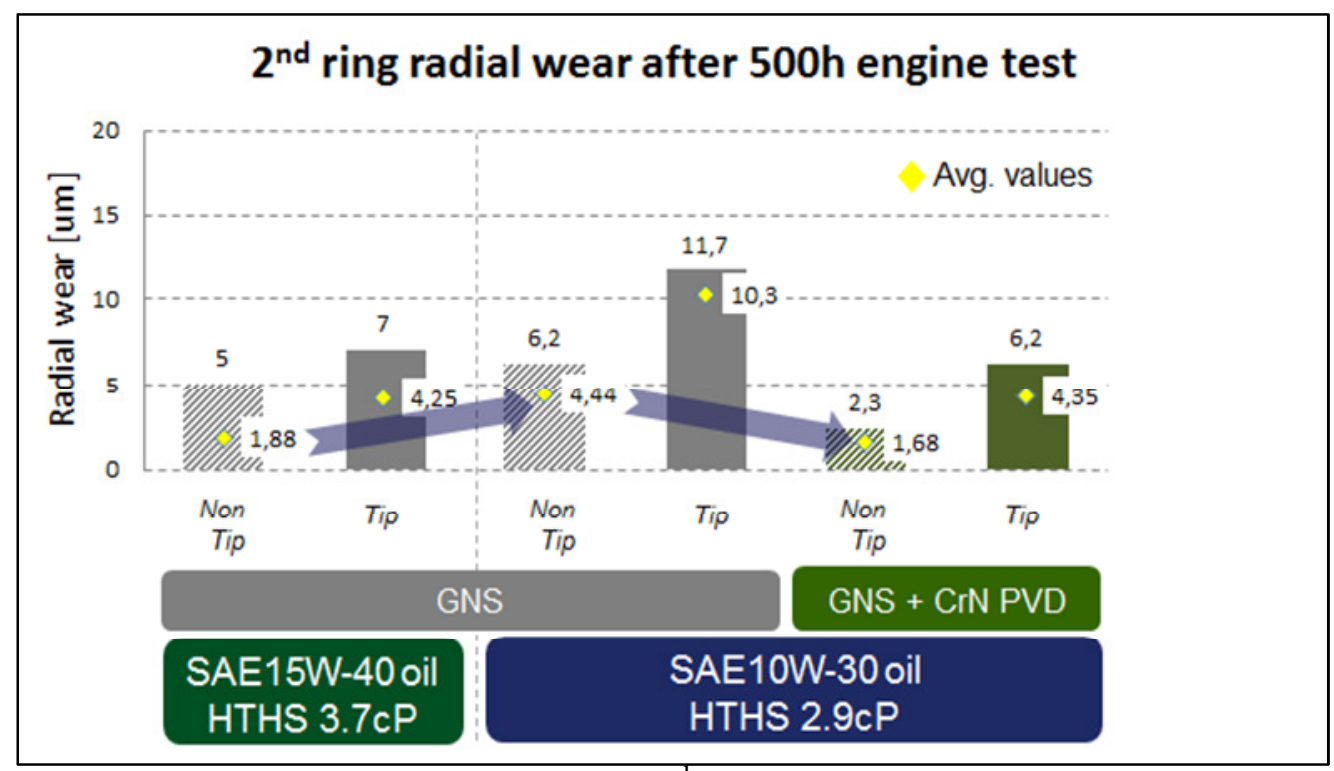

Figure 13 - Radial wear of $2^{\text {nd }}$ ring sets after 500h engine tests.

Similar evaluation was done for the oil control ring, where the DLC H-free over the CrN PVD was compared with the current CrN only oil ring. No issues were found and again the more wear resistant DLC H-free showed lower wear with the low viscosity oil than the current ring with current oil. See figure 14. 


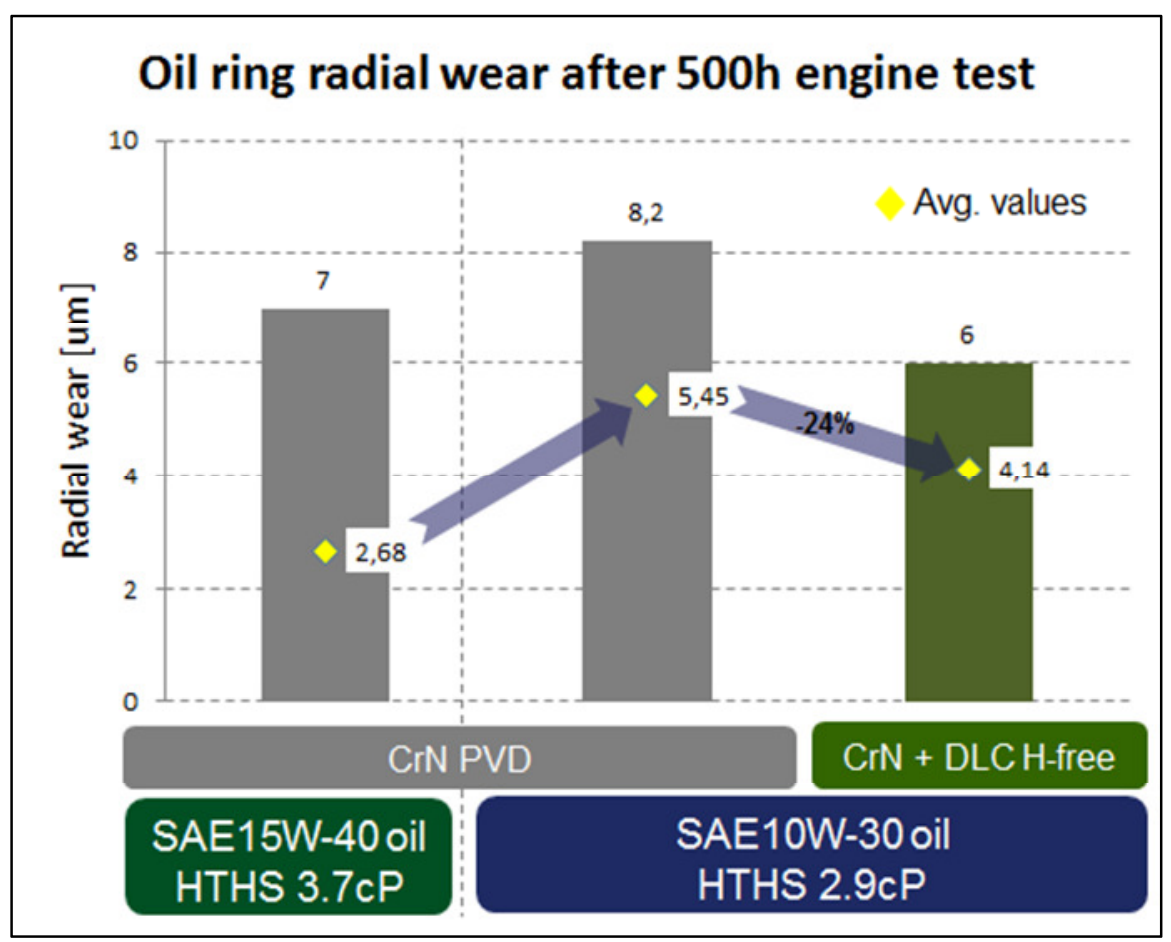

Figure 14 - Radial wear of OCR sets after 500h engine tests.

\subsection{CYLINDER LINERS}

Cylinder liners made in grey cast iron material (DIN GG25) with relative fine honing (a.k.a. "slide honing") honing were assembled in both engine tests. After tests, no severe contact or scuffing signs were found. Wear measurements by axial profile tracer at the critical TDC regions affected by fuel injection showed increased wear depth as expected in both tests. Nevertheless, the avg. wear showed similar results in both engine tests, with different oil viscosities and ring packs, see Figures 15 and 16.

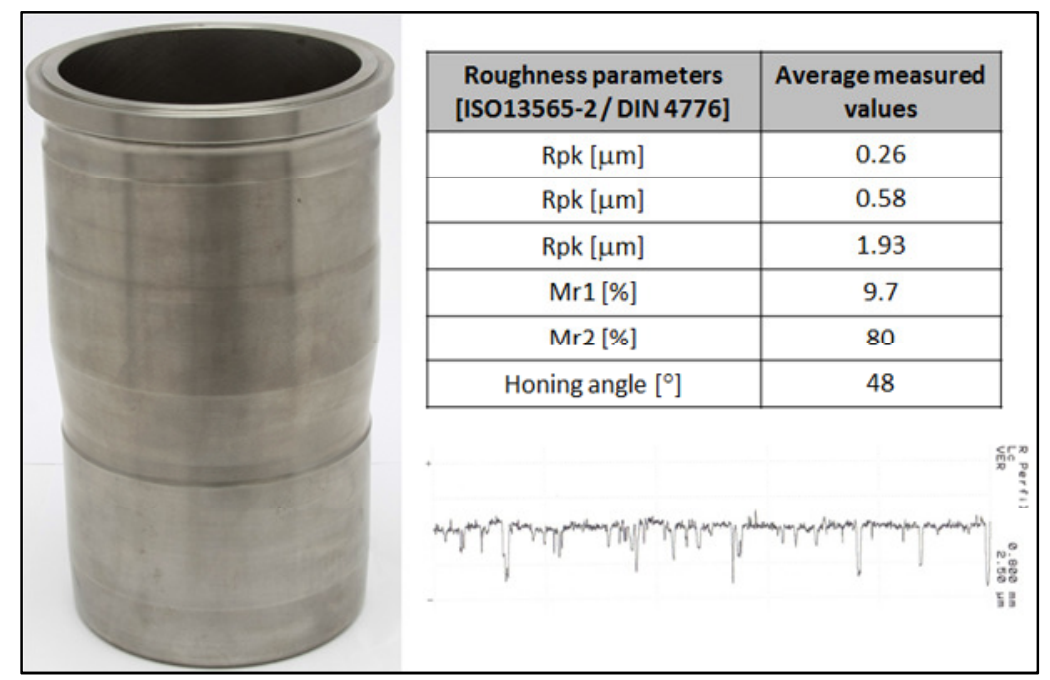

Figure 15 - Iron cast cylinder liner and typical honing roughness values as new. 


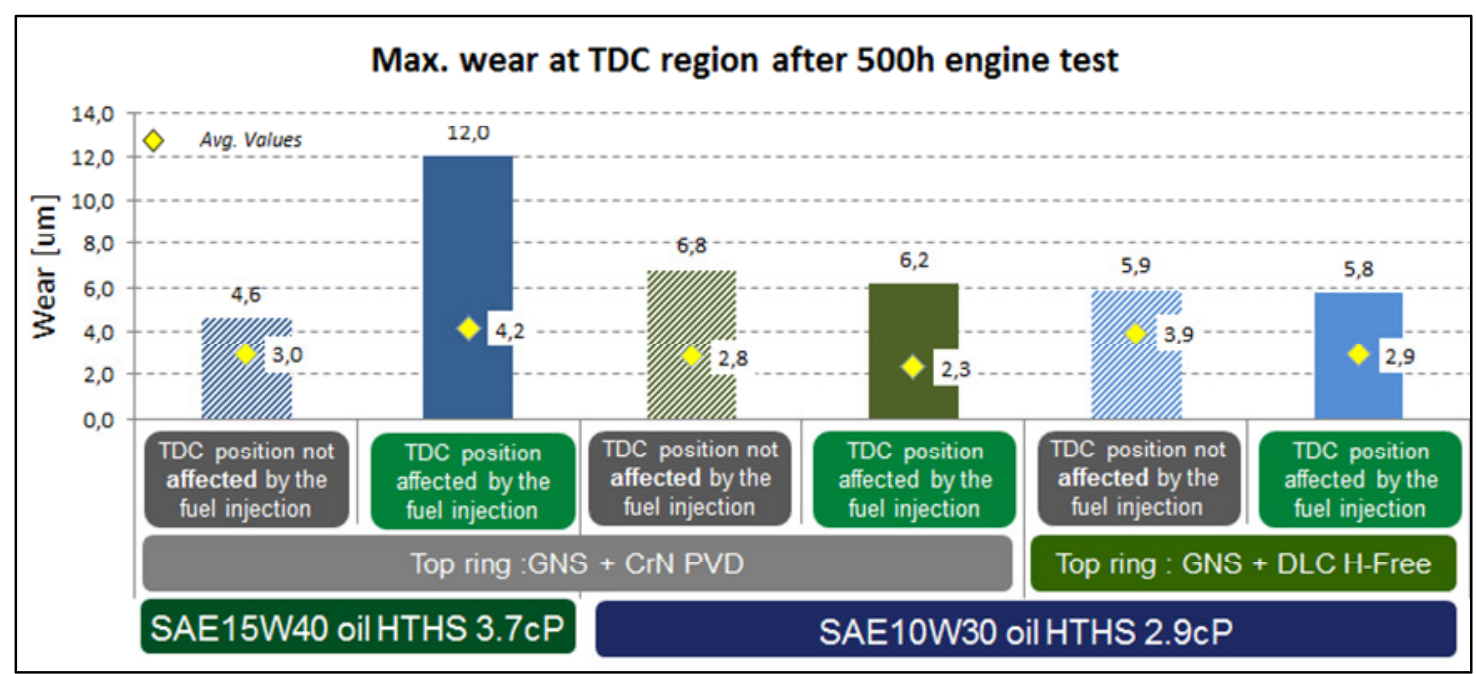

Figure 16 - Wear at liner TDC regions after 500h engine tests.

\subsection{BEARINGS}

The series leaded electroplated upper main bearings (UMB) were assembled in both engine tests. The parts presented good visual aspects and regular contact pattern after test. The lower main bearings (LMB) were assembled using the electroplated lead free technology and presented slightly higher contact pattern compared to UMB, as expected. No scuffing or bronze exposure was noticed on the tested parts. See figure 17. Wear was assessed by wall thickness and weight loss before and after engine tests. The wall thickness and weight loss were similar for the main bearings.

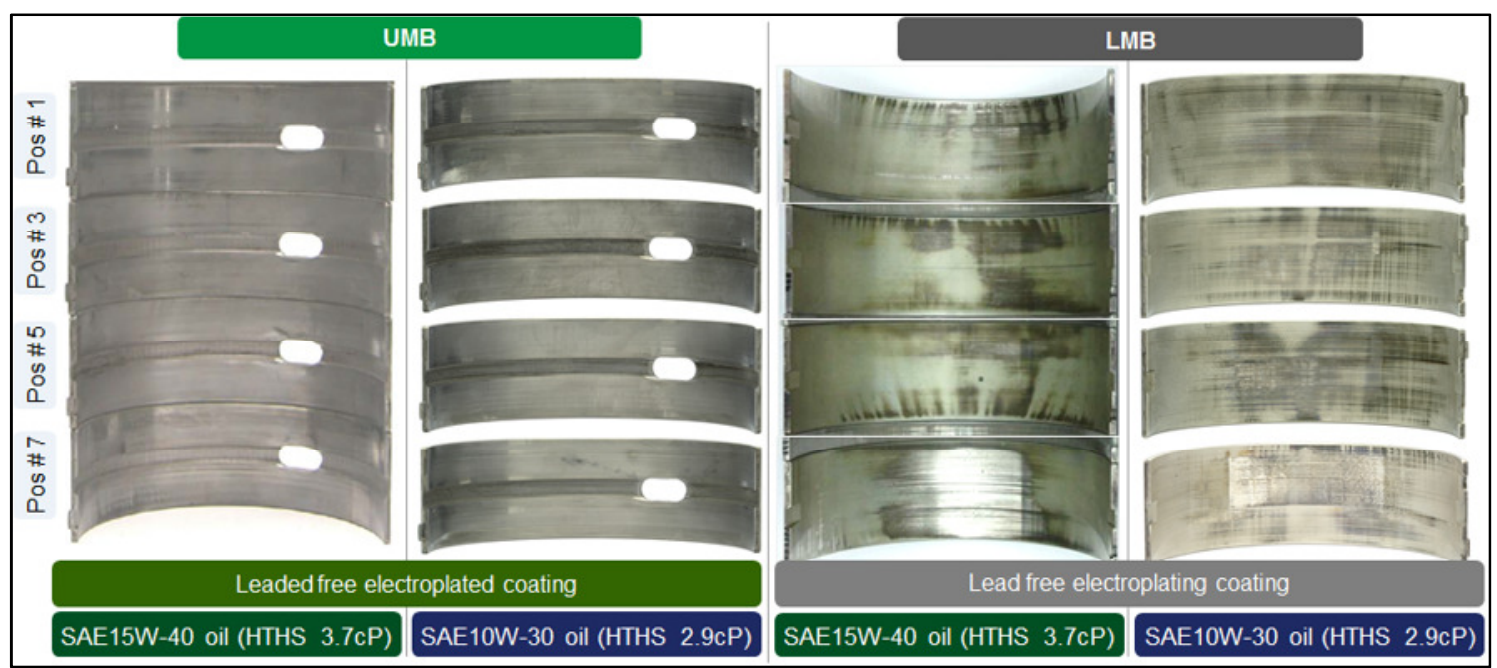

Figure 17 - Visual aspects of UMB and LMB after 500h engine tests.

The upper conrod bearings (URB) were assembled using two coating technologies in both tests. Three cylinders used lead free electroplated bearings and three others, bearings with a high wear resistant polymer coating [12]. For lower rod bearing (LRB) current production, bi-metal lining material was tested in both oil tests. After tests, both upper and lower conrod bearings presented good visual aspects. A wider bearing area was affected using the low viscosity oil. However the wear measurement did not indicate a worst condition. Some scratches were noticed, caused by foreign particles in all parts. No scuffing and no bronze exposure was noticed. See figure 18. Wear was 
assessed by wall thickness and weight loss before and after engine tests. The conrod bearings wall thickness and weight loss were similar for both oil conditions.

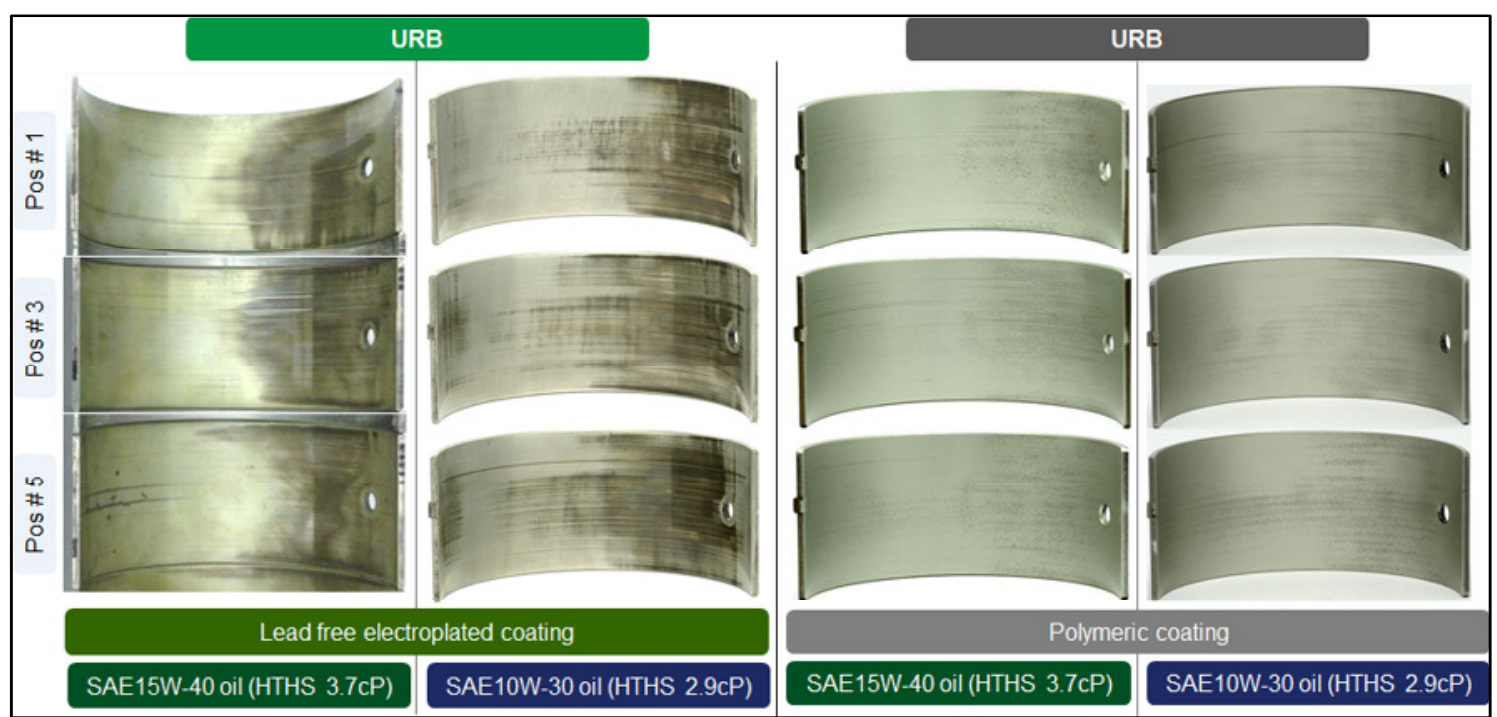

Figure 18 - Visual aspects of URB after 500h engine tests.

\section{CONCLUSION}

The 500h engine test with low viscosity oil 10W-30 and extended drainage time engine was successfully concluded without concerns. Some wear increase was observed on the piston rings but the more resistant alternatives, showed lower wear with the low viscosity oil than the current part with the higher viscosity oil.

Longer tests and analysis of other engine parts are recommended. On the tests components were the wear increase was higher, MAHLE has already alternatives showing lower wear with the low viscosity oil than the current one with the higher viscosity oil.

\section{REFERENCES}

[1] MACIAN, V. et al., "Evaluation of Low Viscosity Engine Wear Effects and Oil Performance in Heavy Duty Engines Fleet Test," SAE Technical Paper 2014-01-2797, 2014.

[2] DAM, W., WILLIS, W., and COOPER, M., "The Impact of Additive Chemistry and Lubricant Rheology on Wear in Heavy Duty Diesel Engines," SAE Technical Paper 1999-01-3575, 1999.

[3] DAM, W. et al., "The Impact of Lubricant Viscosity and Additive Chemistry on Fuel Economy in Heavy Duty Diesel Engines," SAE Int. J. Fuels Lubr. 5(1):459-469, 2011.

[4] DAM, W. et al. "Observations from Cylinder Liner Wear Studies in Heavy Duty Diesel Engines and the Evolution towards Lower Viscosity Heavy Duty Engine Lubricants," SAE Technical Paper 2011-01-1207, 2011.

[5] LEE, P. M., CHITTENDEN R. J., Consideration of Test Parameters in Reciprocating Tribometers used to Replicate Ring-On-Liner Contact. Tribol Lett, 39:81-89, 2010. 
[6] DAM, W., BOTH, J., and PARSONS, G., "Taking Heavy Duty Diesel Engine Oil Performance to the Next Level, Part 1: Optimizing for Improved Fuel Economy," SAE Technical Paper 2014-01-2792, 2014.

[7] MORTIER, R., FOX, M., ORSZULIK, S., Chemistry and Technology of Lubricants. $3^{\text {rd }}$ Edition. Springer. pg $108-117,2010$.

[8] Taylor, O. et al., "Tribological Behavior of Low Viscosity Lubricants in the Piston to Bore Zone of a Modern Spark Ignition Engine," SAE Technical Paper 2014-01-2859, 2014.

[9] BADAL, L., "Challenges in implementing PC-11". Tribology \& lubrication technology magazine, vol. 72, nr. 1, Jan. 2016

[10] PROFITO, F. et al. "Effect of lubricant viscosity and friction modifier on reciprocating tests" SAE Technical Paper 2013-36-0155, 2013.

[11] BRUNO, R.; FARIA, G.; SILVA, D. "Improvements on ring pack performance by using PVD coating" SAE Technical Paper 2013-36-0374, 2013.

[12] FERREIRA, M. et al., "Polymeric Coated Lead Free Bronze Bearings for High Durability in Medium Duty Diesel Engines," SAE Technical Paper 2014-36-0405, 2014.

[13] LOPEZ, D. et al "Innovative kohlenstoffbasierte Beschichtungskonzepte fur Kolbenringe" - VDI-Fachtagung mit Fachausstellung, 2016

\section{DEFINITIONS / ABREVIATIONS}

$\begin{array}{ll}\text { API } & \text { American Petroleum Institute } \\ \text { AN } & \text { Acid number } \\ \text { BN } & \text { Base number } \\ \text { DLC H-free } & \text { Diamond-like carbon hydrogenated free coating } \\ \text { EMA } & \text { Engine Manufacturers Association } \\ \text { GNS } & \text { Gas nitrited steel } \\ \text { GHG } & \text { Greenhouse Gas } \\ \text { HDD } & \text { Heavy Duty Diesel } \\ \text { HTHS } & \text { High Temperature High Shear } \\ \text { ICP-OES } & \text { Inductively Coupled Plasma - Optical Emission Spectrometer } \\ \text { LMB } & \text { Lower main bearing } \\ \text { LRB } & \text { Lower rod bearing } \\ \text { LOC } & \text { Lube oil consumption } \\ \text { OEM } & \text { Original Equipment Market } \\ \text { TDC } & \text { Top dead center } \\ \text { UMB } & \text { Upper main bearing } \\ \text { URB } & \text { Upper rod bearing } \\ \text { ZnDtp } & \text { Zinc-dithiophosphates }\end{array}$

